\title{
Flow Behavior of Dispersed Composite Polymer Melts
}

\author{
by \\ Masayuki Kasajima, Akira Suganuma, Daizo KuniI \\ (Faculty of Engineering, University of Tokyo, Bunkyo, Tokyo 113) \\ and Katsuhiko ITo \\ (College of Engineering, Hosei University, Koganei, Tokyo 184)
}

\begin{abstract}
When two different polymers are mechanically blended, the flow curve of the composite melt does not always lie in between the curves for the component polymers. In order to find the condition for this phenomenon to occur, we measured the flow curves of blends of a polystyrene (PS) and a high density polyethylene (HDPE) with a Thixotrometer. Four samples of PS of various fluidities were examined. The fluidity of HDPE was higher than any PS samples at the temperature of measurements, $200^{\circ} \mathrm{C}$.

When the fluidity of PS was very low and much apart from that of HDPE, the flow curves for the blends lay between those of PS and HDPE at any blend ratio. As the fluidity of PS increased and approached that of HDPE, the flow curve for the blend of high PS content, i.e., 0.75 , became to intersect that for the PS; the blend exhibited a fluidity lower than even the component PS at low rates of shear. In the case of the PS of the highest fluidity, the blend of high PS content exhibited fluidity lower than the PS over the whole range of rate of shear studied. These results were discussed in terms of a proposed phenomenological blending law.
\end{abstract}

\section{分散系複合高分子溶融体の流動挙動}

\author{
笠島 正行・菅沼 彰・国井 大蔵 ${ }^{* 1}$ - 伊藤 勝彦*2
}

(原稿受理：1978年12月25日)

\section{1. 緒言}

品質改良や資源の有効利用，廃棄物公害防止の見地加ら異種材 料混合系プラスチックへの関心が持たれており, 異種高分子を分 散系で複合化した材料をレジンアロイ1)あるいはプラスチックア ロイ ${ }^{2)}$ ，広い意味ではブレンドポリマー1),3) と言った呼称が既に

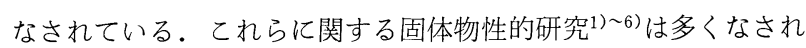
ているが，実際の成形加工時に必要な流動特性に関する研究3),7) 〜13) はかなり行われるようになったとはいえ，単一均質材料のそ

*1 東京大学工学部 東京都文京区本郷

*2 法政大学工学部 東京都小金井市梶野町
れに比べ知見が十分得られているとは言えない。機械的に混合し た非相溶性樹脂の組み合わせのようなマク口複合溶融体の流動特 性に関する屯のについてあそれほど多くはないようである。この ような試料の流動特性は一般に相加性が成り立たない場合が多く 9),10), 流動挙動はそう単純なものではない. また, 混合試料の流動 特性曲線が単一成分試料の曲線の外側に出るような特異流動現象 が組み合わせる試料の種類によっては生じる場合がある ${ }^{10), 12), 13)}$. これらの挙動は混合比やせん断速度などによっても影響を受け, 複雑な流動挙動を示す．乙のような複合化の方法においては各単 一成分試料の性質を効果的に引き継いだり，あるいは新たな性質 を生み出しうる可能性があり興味のあるあのであるが, 流動機構 
等についてはまだ明らかでないととが多いようである.

本報では, 混合試料の流動特性曲線が単一成分試料の曲線の外 側に出る特異現象がどのように発生するかを調べるために，異種 高分子材料を機械的に混合した分散系複合高分子溶融体を用いた。 組み合わせる試料の一方は変えず，あう一方の試料を同種の樹脂 で流動性を異にするようにグレードを変え，それぞれ組み合わせ た。このような複合方法によって流動挙動がごのように変化する かを, 混合率を変えて流動特性を测定, 検討した結果について報 告する.

\section{2. 実}

\section{験}

試料はポリスチレン(PS)樹脂と, 高密度ポリエチレン(HDPE) 樹脂を組み合わせたものである. HDPE 1 種類に流動性の異なる PS 4 種類をそれぞれ組み合わせた。 HDPE は昭和油化㑣製の Sholex F6120V であり, PS は電気化学工業妋つ Denka Styrol, グレードは MW-1 (当報文中ではPS1 と表示. 以下同様), HRM -2 (PS 2), GP-1 (PS 3), QP-2(PS 4) である. 混合形態は機械 的に混合した分散系であり, 混合試料の作成は次のような手順で 行った. 組み合わせる樹脂をペレット状態で小型回転円筒混合機 を用いて混合した後, 小型スクリュ一押出機を通し, 押し出され た試料を粉砕機で粉砕した。それを流動特性測定時の試料とした。 なお，混合試料と比較する各単一成分試料についても混合試料が 受けたと同様の履歴を持たせた。混合試料中の流れにくい方の成 分の重量分率を混合率 $c$ 之定義した。混合試料名の表示は例えば， PS1·HDPE の形式で行った。 この際先に記された試料の方が後

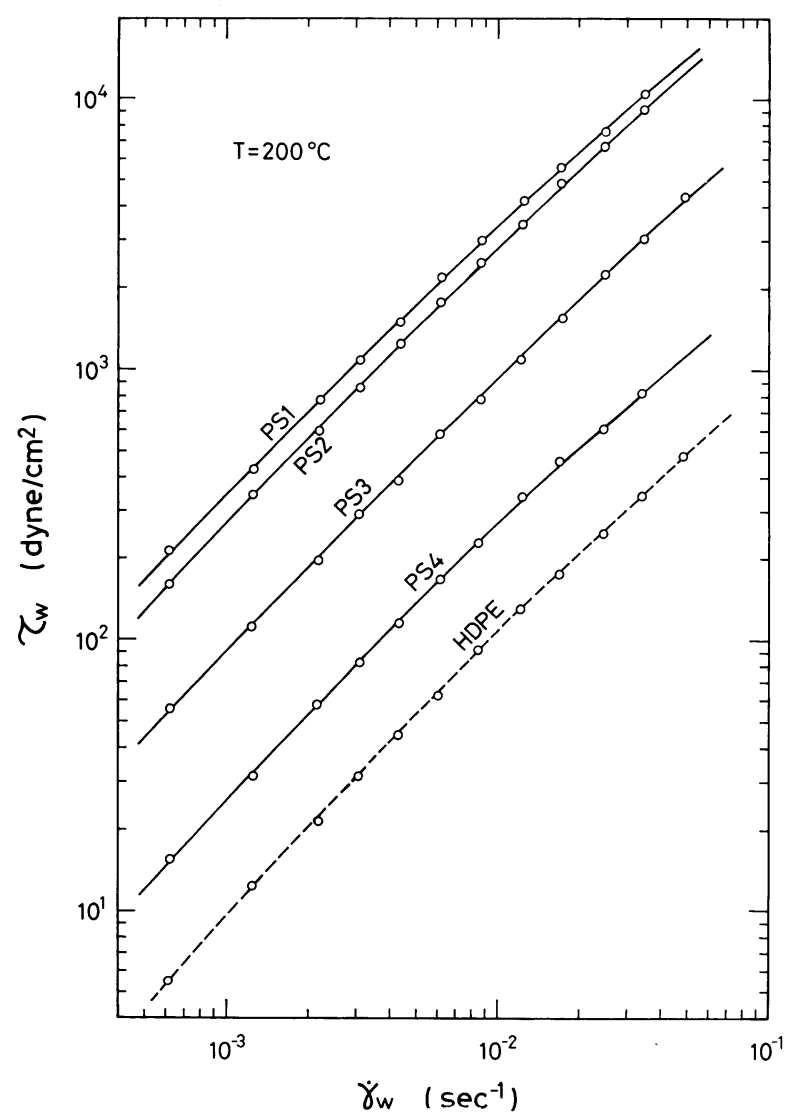

Fig. $1 \tau_{w}-\dot{\gamma}_{w}$ flow characteristic curves for PS1 $\sim$ PS4 and HDPE samples.
記の試料に比べ流れにくい成分であるととを表している．混合比 は下付き数字で表示する.流動特性の測定はチクソトロメータを 用いて行った。

\section{3. 結果と考察}

PS1〜PS4 と HDPE 各単一成分のせん断応力 $\tau_{w}$ - せん断速度 $\dot{\gamma}_{w}$ 流動特性曲線を Fig. 1 亿示す. Fig. 1 から明らかなように各 試料の流動性の良さの程度は, HDPE $>$ PS $4>\mathrm{PS} 3>\mathrm{PS} 2>\mathrm{PS} 1$ で ある. これら流動特性の $\tau_{w}$ の $\dot{\gamma}_{w}$ 依存性の形態はほぼ似たもので ある.Fig. 2 亿当実験で用いた試料中では，一番流動性の良くな いPS1 を HDPE に組み合わせた場合について，c を助变数とし た $\tau_{w}$ と $\dot{\gamma}_{w}$ の関係を示す. この図から混合試料の曲線は $c$ の異な る曲線が交差することなく, 各単一成分試料の曲線間に位置する ことがわかる。そして，その位置の仕方は $c$ の大きい順に上から 下に配列する. これらのことはポリプロピレン $(\mathrm{PP})$ 樹脂・HDPE 混合試料等の結果 ${ }^{9)}$ と似た挙動のあのである. PS2·HDPE 混合試 料の $\tau_{w}-\dot{\gamma}_{w}$ 流動特性の結果を Fig. 3 亿示す. 乙の図において $\dot{\gamma}_{w}$ が大きい領域では, PS1·HDPE 混合試料の場合と同様に 各混合 率の流動特性曲線は, 単一成分試料の曲線間に位置しているが, $\dot{\gamma}_{w} \fallingdotseq 1.7 \times 10^{-3} \mathrm{sec}^{-1}$ 付近で $\mathrm{PS}_{75} \mathrm{HDPE}_{25}$ の曲線は, $\mathrm{PS}_{100}$ の曲 線之交差する。 そして, $\dot{\gamma}_{w}$ がそれより小さい領域になると $\mathrm{PS} 2_{75}$. $\mathrm{HDPE}_{25}$ 曲線は, PS2 100 曲線の流机にくい側であるところの外側 にわずかではあるが出るようになる. Fig. 2, 3 亿扔いて, $c=0.5$ の曲線は他の混合率のものより $\tau_{w}$ の $\dot{\gamma}_{w}$ 依存性がやや弱い。すな

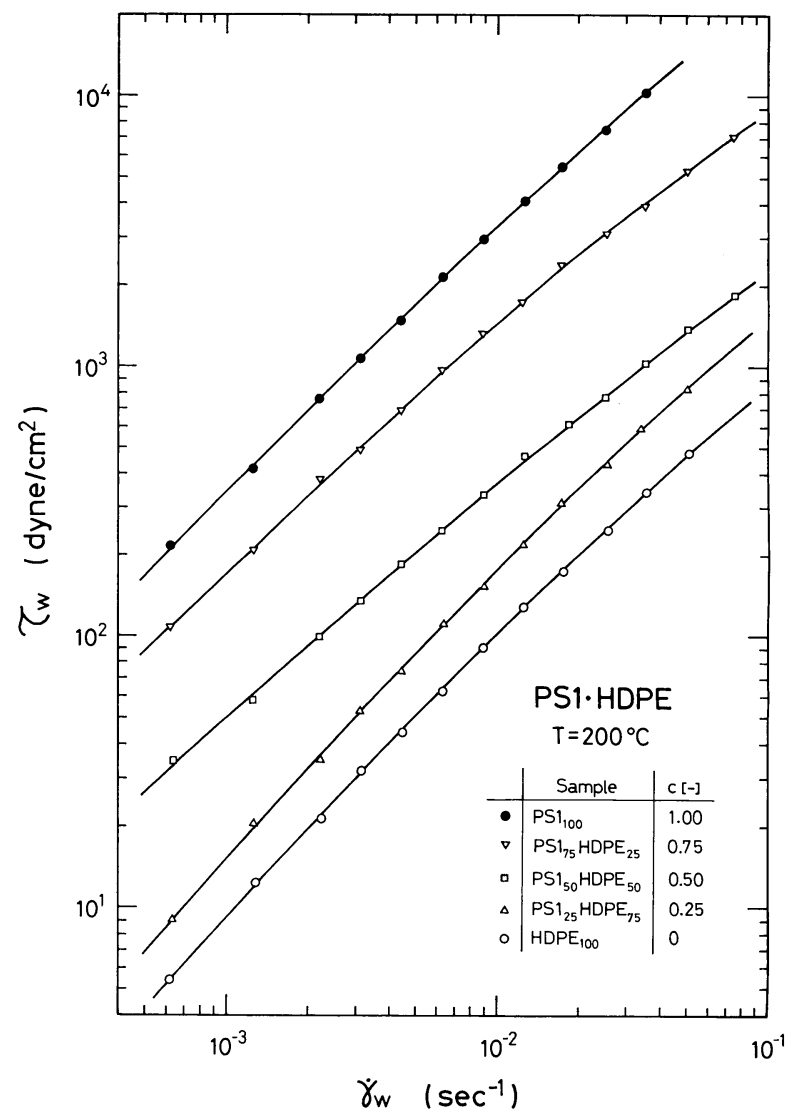

Fig. $2 \tau_{w}-\dot{\gamma}_{w}$ flow characteristic curves for blended PS1.HDPE samples, 
わち, この混合率の曲線は傾きがゆるく, $\dot{\gamma}_{w}$ が増加するに従って HDPE 側に寄るような傾向を示す.乙れは他のcの曲線より目立

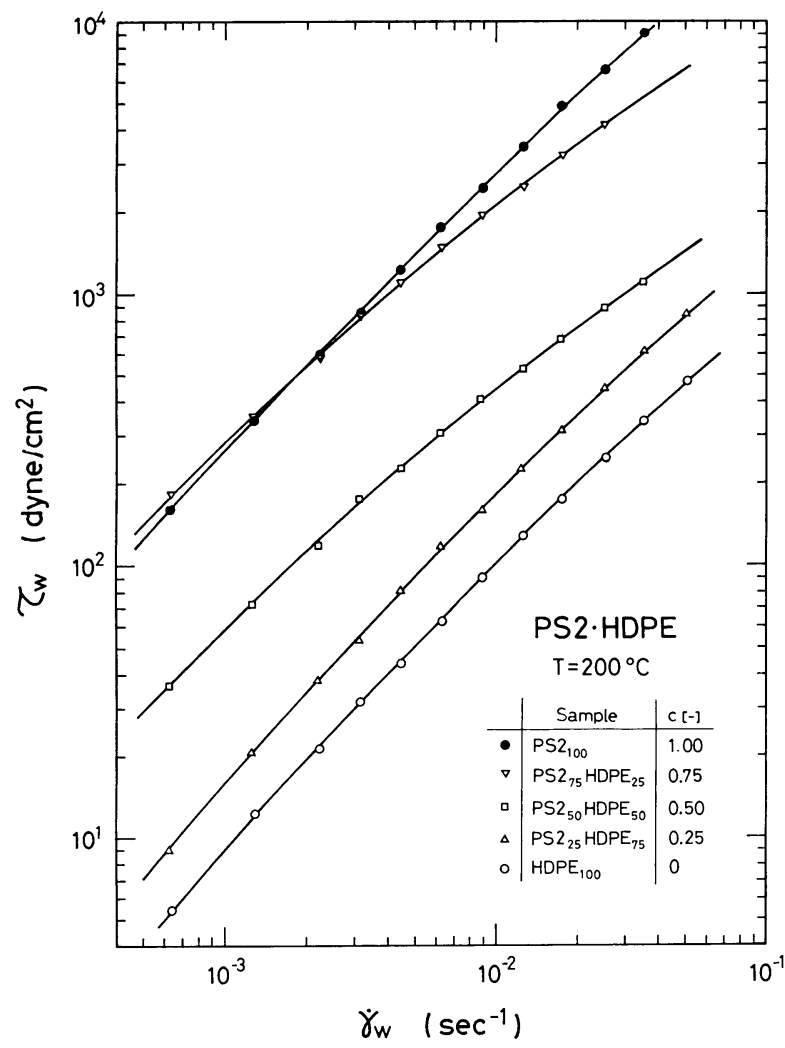

Fig. $3 \quad \tau_{w}-\dot{\gamma}_{w}$ flow characteristic curves for blended PS2 - HDPE samples.

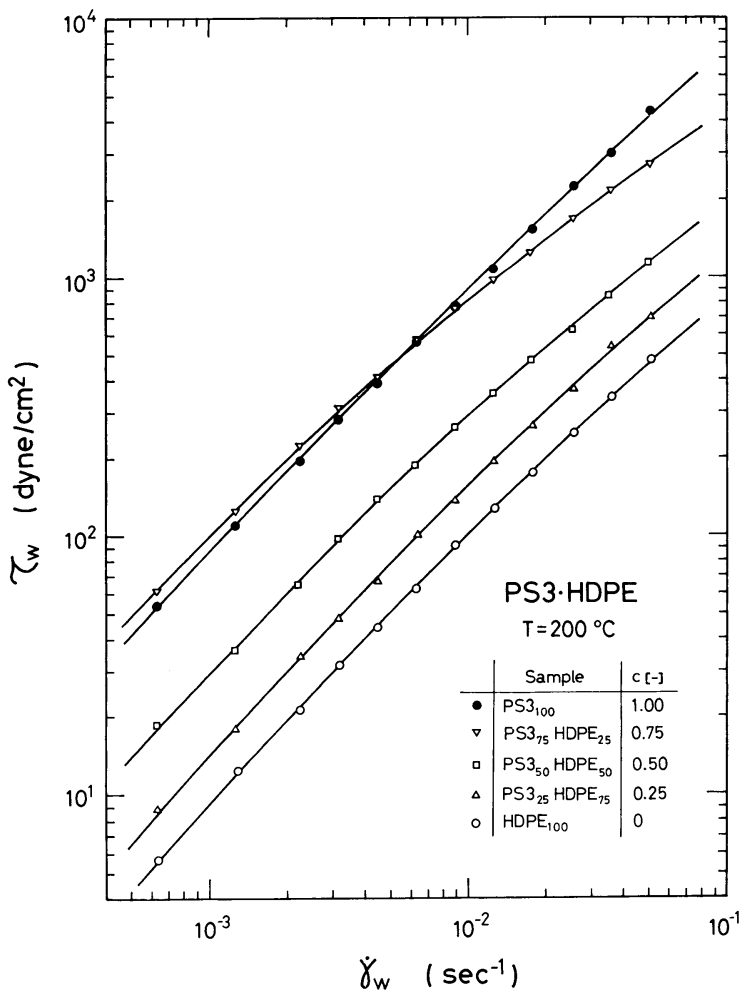

Fig. $4 \tau_{w}-\dot{\gamma}_{w}$ flow characteristic curves for blended PS3·HDPE samples.
つあのである.PS2 はPS1に比べ流動性が良いので, PS2 とHDPE 曲線の間隔は狭まっていることなどの相違はあるが, $\mathrm{PS}_{75} \mathrm{HDPE}_{25}$ 以外の混合試料が単一成分試料間に位置することなど似た傾向の あのである. PS3・HDPE 混合試料の流動特性は Fig. 4 亿示す. この図において, $\mathrm{PS}_{75} \mathrm{HDPE}_{25}$ 曲線が $\mathrm{PS}_{100}$ 曲線と $\dot{\gamma}_{w}=5 \times 10^{-3}$ $\mathrm{sec}^{-1}$ 付近で交差し， $\dot{\gamma}_{w}$ がてれより小さい領域では $\mathrm{PS}_{75} \mathrm{HDPE}_{25}$ 曲線は PS3 $3_{100}$ 曲線の上側に位置する. PS2 HDPE 混合試料の場 合よりも PS3・HDPE 混合試料の方が交差する $\dot{\gamma}_{w}$ の位置がやや 大きく, $\dot{\gamma}_{w}$ が小さい領域で $\mathrm{PS}_{75} \mathrm{HDPE}_{25}$ が $\mathrm{PS}_{100}$ より外側に出 る程度も幾分大きくなっている. PS4.HDPE 混合試料の流動特 性を Fig. 5 亿示す. PS4 は本実験で用いた PS 群中一番流動性 が良く, 他の PS に比べ HDPE の流動特性曲線に対する位置関 係が最も近い. PS4.HDPE 混合試料では, $\mathrm{PS}_{75} \mathrm{HDPE}_{25}$ 曲線が $\mathrm{PS}_{100}$ 曲線に対し流れにくい側であるとてろの外側に $\dot{\gamma}_{w}$ の全領 域にわたって位置する。そして，その外側に出る程度，すなわち 離れる程度は $\dot{\gamma}_{w}$ が大きい領域よりあ小さい領域の方が大である. このことは PS2·HDPE と PS3・HDPE 混合試料において, $\mathrm{PS}_{75}$ $\mathrm{HDPE}_{25}$ の曲線を $\dot{\gamma}_{w}$ 軸に沿って $\dot{\gamma}_{w}$ を減少する方向に平行移動 させ， $\mathrm{PS}_{100}$ の曲線を越えた場合の位置関係似似たものである。 以上のことから HDPE を基にした場合, 組み合わせる PS の流 動性の相違により, 流動特性曲線上で一部の混合率のものが単一 成分試料の曲線の外に出る特異現象を生じる. この特異現象の発 生は, HDPE の流動性に比べて一番流動性の悪い PS1 を組み合 わせた場合には無く，流動性の良い PS2…...PS4 と組み合わせて 行くに従って顕著になることがわかる.

各組み合わせ試料について, $\dot{\gamma}_{w}$ を助変数とした $\tau_{w}$ と $c$ との関 係を Fig. 6〜9 亿示す. PS1.HDPE 混合試料の $\tau_{w}-c$ 曲線は, $\dot{\gamma}_{w}$ とcが小さい範团では比例配分線を表す破線より下に離れた下向 きの凸である。しかし，cが大きく $\dot{\gamma}_{w}$ が小さな領域では比例配 分線加々に越えた上向きの凸状になる。そして $\dot{\gamma}_{w}$ の減少とと 屯に比例配分線をはさんで形状が $\mathrm{S}$ 字状に変化して行く. PS2. HDPE 混合試料では, PS1·HDPE 混合試料の場合に比べるとc

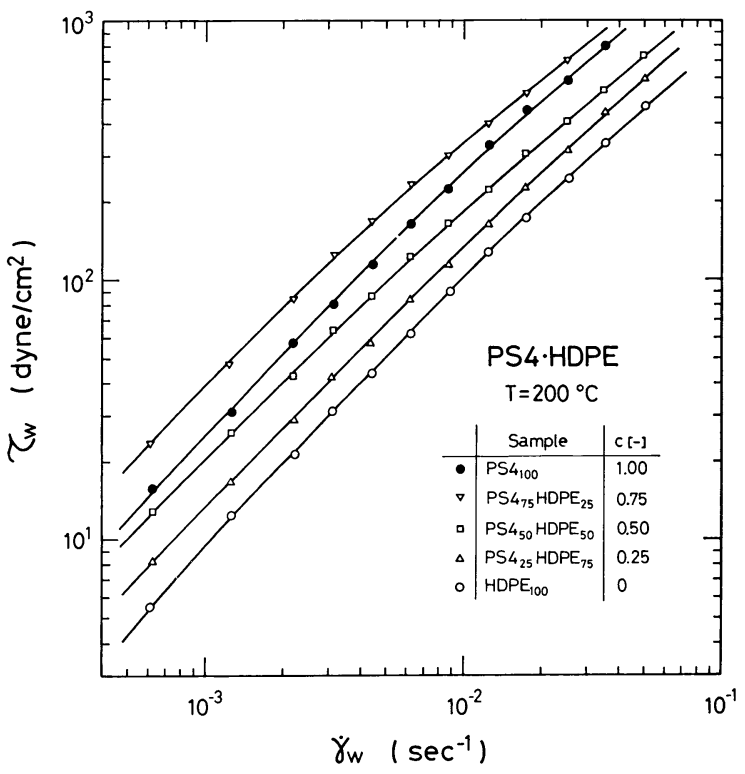

Fig. $5 \quad \tau_{w}-\dot{\gamma}_{w}$ flow characteristic curves for blended PS4·HDPE samples. 


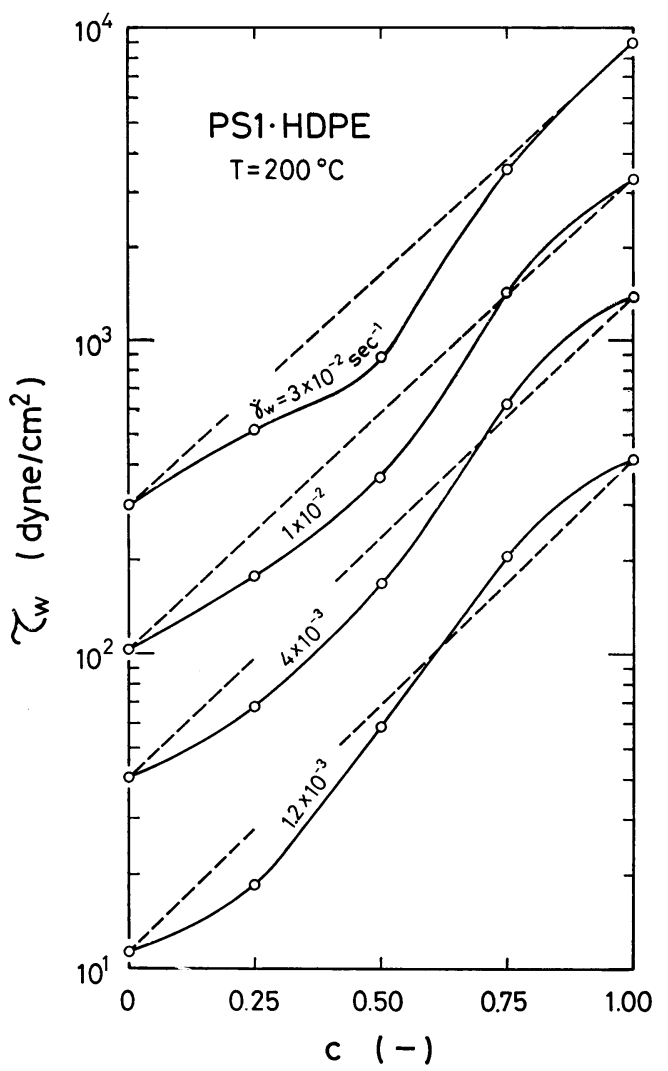

Fig. $6 \tau_{w}-c$ curves for blended PS1.HDPE samples.

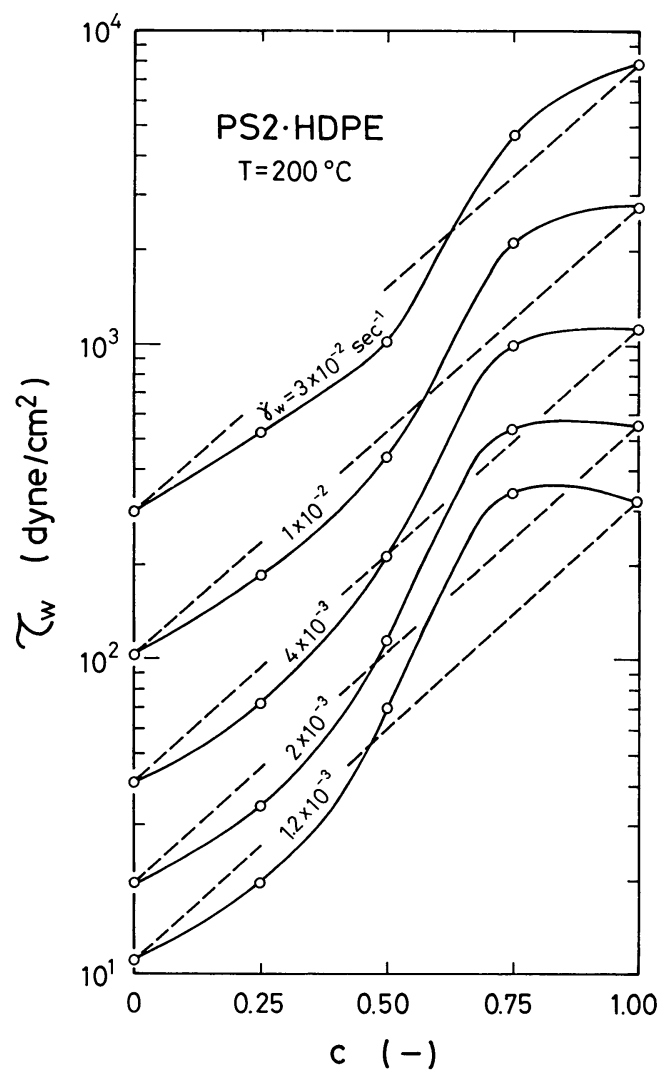

Fig. $7 \tau_{w}-c$ curves for blended PS2.HDPE samples.

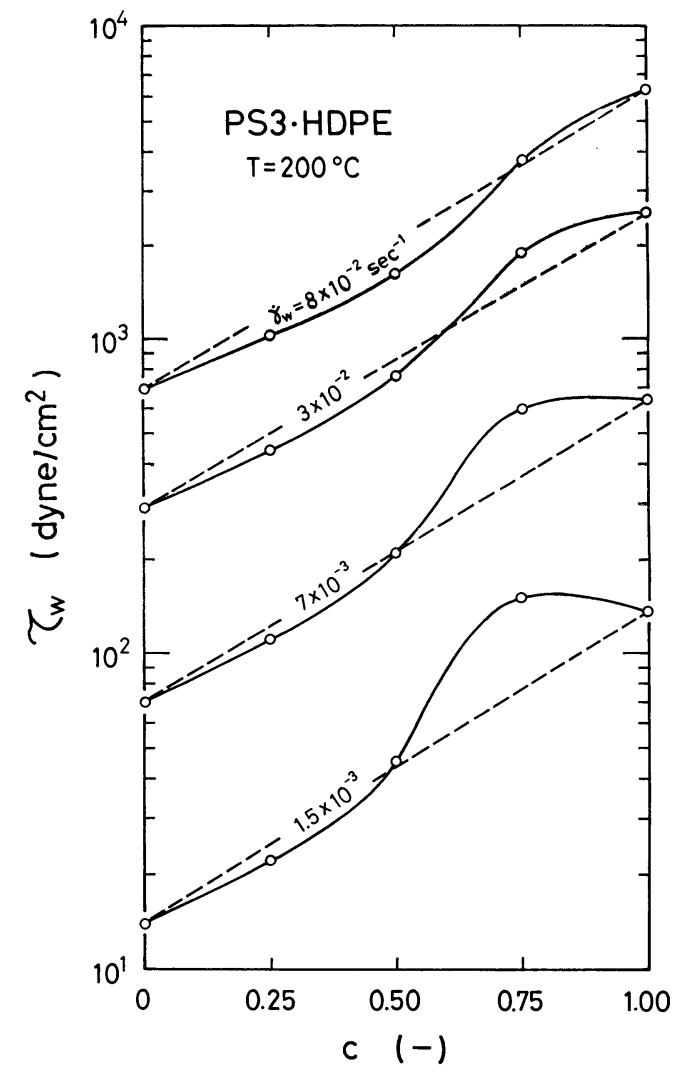

Fig. $8 \tau_{w^{-c}}$ curves for blended PS3.HDPE samples.

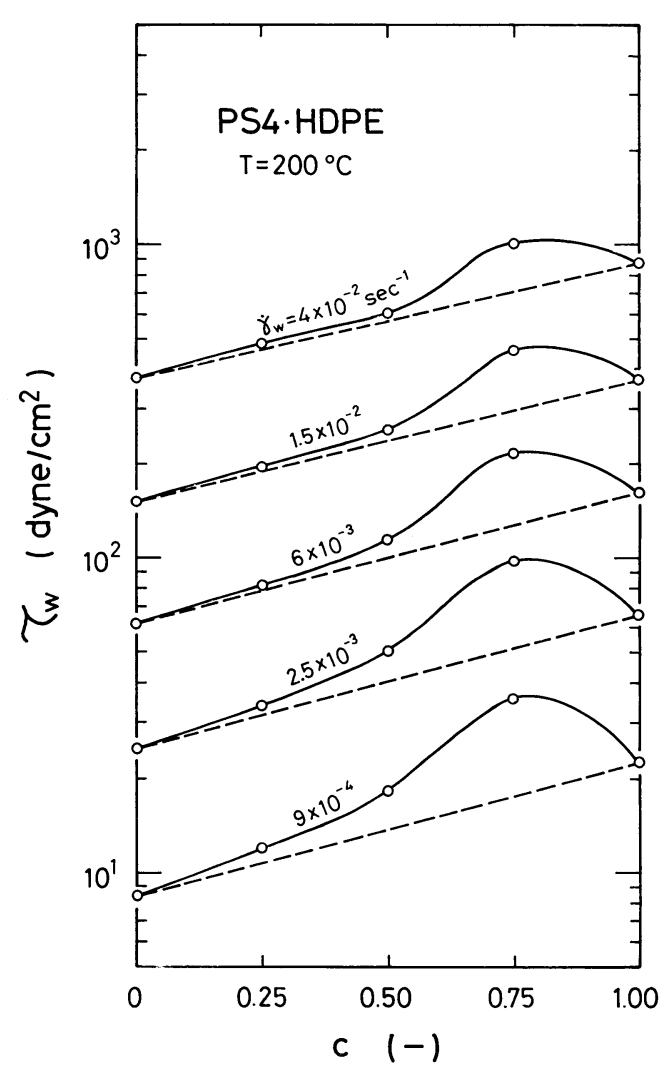

Fig. $9 \widetilde{\tau}_{w^{-c}}$ curves for blended PS4.HDPE samples. 
の大きな領域で比例配分線からのずれの程度が大くなり, 曲線形 状の S 字状に変化する程度も大きくなる。 PS $3 \cdot \mathrm{HDPE}$ 混合試料 では, $c$ の小い範囲では比例配分線からのずれが小さく, $c=0.5$ における $\dot{\gamma}_{w}=7 \times 10^{-3}, 1.5 \times 10^{-3} \mathrm{sec}^{-1}$ での $\tau_{w}$ の值は比例配分 とほぼ一致, すなわち相加性が成り立っている.しかし, $c=0.75$ で $\dot{\gamma}_{w}$ が小なる領域では, 此例配分線より上にずれる程度が著し く大きくなる. PS4.HDPE 混合試料での $\tau_{w}-c$ 曲線は, 比例配分 線より上側に位置し，cが小さな領域では比例配分線に近い位置 関係にあるあのが, $c$ が大きくなるに従って離れ，特に $c=0.75$ で顕著になり，ほぼその付近でピークを示すようになる。

相加性からのずれの程度にたいし，異なる組み合わせ混合試料 間の相対比較検討を容易にするために, 式(1)～(3)に示す高分子混 合溶融体の流動特性を表す一表示式 ${ }^{9), 13)}$ 加ら求まる有効混合率 $c^{*}$, 混合率補正係数 $\phi$ を用いると都合よいので, それらの值を求め検 討することにする。

$$
\begin{aligned}
\ln \left\{\tau_{1 \cdot 2}(\dot{\gamma}, T)\right\}= & \phi(c, \dot{\gamma}, T) c \ln \left\{\tau_{1}(\dot{\gamma}, T)\right\} \\
& +[1-\phi(c, \dot{\gamma}, T) c] \ln \left\{\tau_{2}(\dot{\gamma}, T)\right\}
\end{aligned}
$$

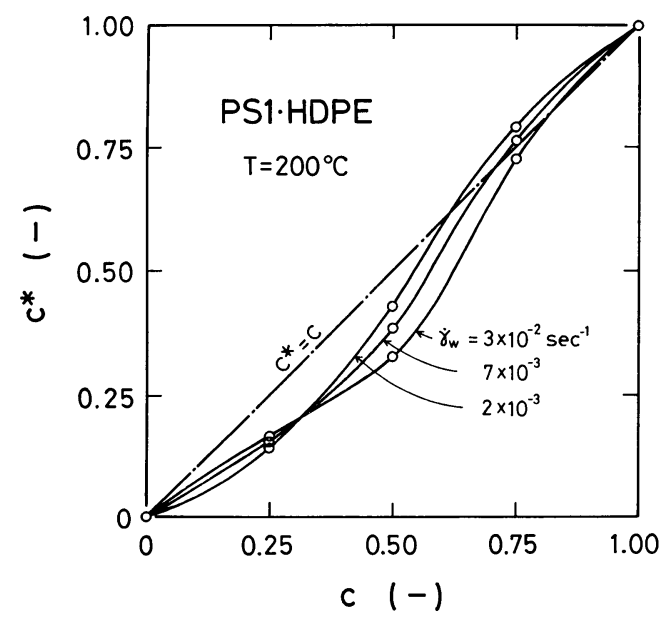

Fig. 10 Relationship between $c^{*}$ and $c$ for blended PS1·HDPE samples.

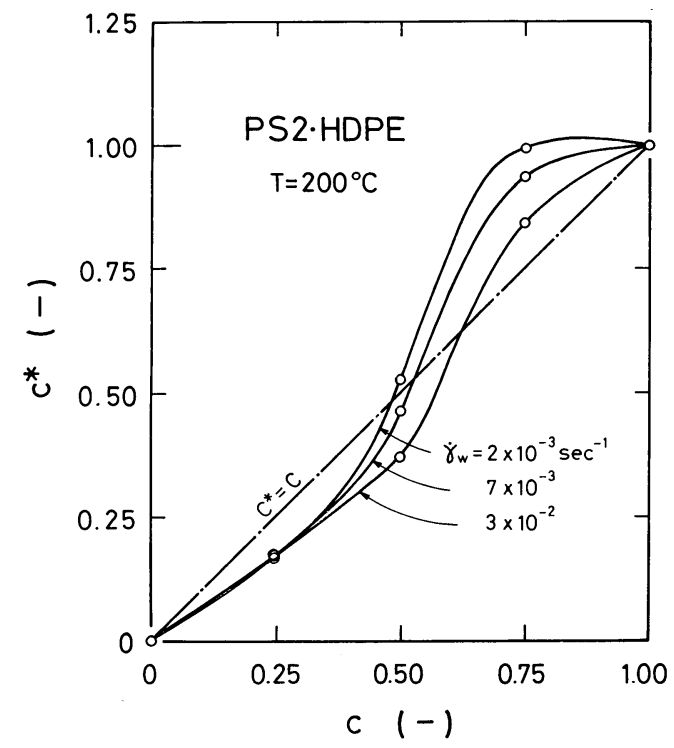

Fig. 11 Relationship between $c^{*}$ and $c$ for blended PS2·HDPE samples.

$$
\begin{gathered}
\phi=\sum_{j=0}^{i}\left\{\lambda_{j}(c, T)\right\}(\ln \dot{\gamma})^{j} \\
c^{*}=\phi(c, \dot{\gamma}, T) c
\end{gathered}
$$

ここで, c は混合率, $T$ は温度, $\dot{\gamma}$ はせん断速度, $\tau$ はせん断応 力, 下付き添字の 1 は第 1 成分, 2 は第 2 成分, $1 \cdot 2$ は混合物で ある。

式(1), (3) と Fig. 2 5 亿示すそれぞれの $\tau_{w}-\dot{\gamma}_{w}$ 流動特性曲線 から $\dot{\gamma}_{w}$ に対する各混合試料の $c^{*}$ を算出し，その結果を Fig. 10 〜13 に示す. PS1·HDPE 混合試料は, 流動特性曲線上ですべて の混合試料が両単一成分試料の間に入ったものであるが, Fig. 6 から明らかなように相加性は成り立ない， $c^{*} は c に$ 対して変化す

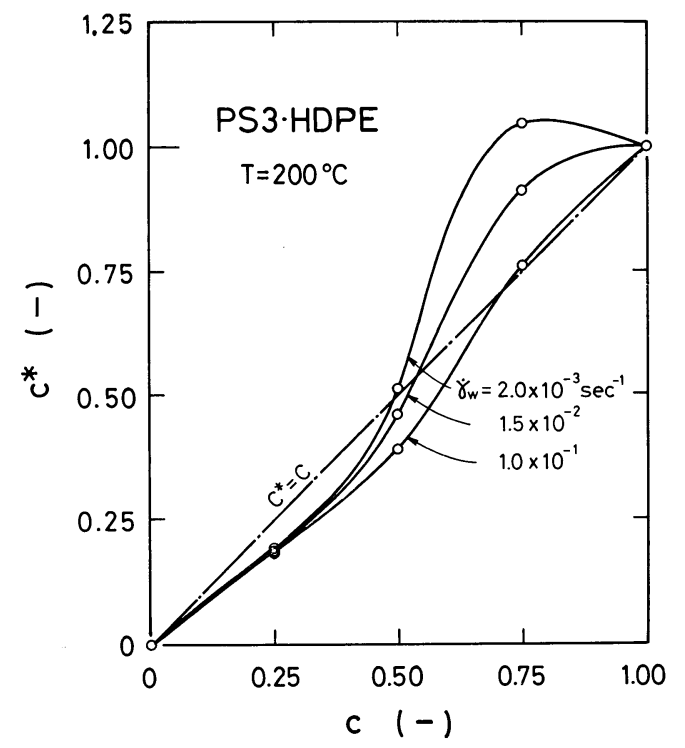

Fig. 12 Relationship between $c^{*}$ and $c$ for blended PS3.HDPE samples.

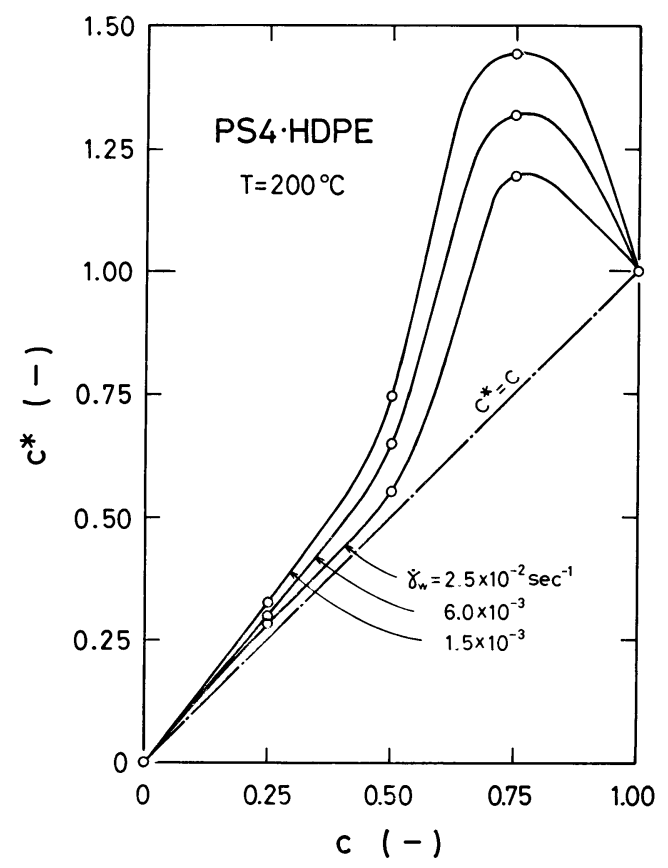

Fig. 13 Relationship between $c^{*}$ and $c$ for blended PS4.HDPE samples. 
るばかりでなく $\dot{\gamma}_{w}$ によっても変わり, $c^{*}$ の曲線は変曲点を持ち, $c$ が小さい範囲では $c^{*}=c$ で表した直線より下側にずれた凸であ るが，cが大きな所では上側に幾分出た凸になる，すなわち，c が小さい範囲では混合試料の流動特性は流れやすい HDPE 成分 の流動性に支配される程度が大きく，cが大きな所では流れにく い PS 成分の流動性に支配される程度が少し大きくなる．PS2. HDPE 混合試料の $c^{*}$ と の関係は PS1.HDPE 混合試料の場合 に比べ, $c^{*}=c$ 直線より上に 位置する $c$ の範囲が広くなり, $c=$ 0.75 付近ではその程度が更に大となる. $c=0.25$ 付近においては PS1:HDPE 混合試料では $\dot{\gamma}_{w}$ による変化が少しあるが, PS2. HDPE，PS3·HDPE混合試料になるとほとんど変化がなくなる。 $\mathrm{PS} 3 \cdot \mathrm{HDPE}$ 混合試料での $c^{*}-c$ 曲線は $c^{*}=c$ 直線を越えて上に出 る程度がより大きくなる. PS4. HDPE 混合試料は $\dot{\gamma}_{w}$ を助変数之 する $c^{*}$ 曲線は $c$ の全領域にわたり $c^{*}=c$ を表す直線より上側に あり,そのずれの程度は $\dot{\gamma}_{w}$ が小さいほど大きい.すなわち, 混 合試料の流動は流れにくい PS 成分の流動性にかなり支配されて いる. $c=0.75$ 付近でその程度は非常に大きく，しかも $c^{*}=1$ を 超えた值をとる. このことは混合という操作により両単一成分試 料の持っている流動性以外の特異な流動挙動を生じたことになる.

Fig. 10〜13 は Fig. 6〜9でのものと異なり共通化した尺度の c*を用いているので, 乙れらの図において同じ $\dot{\gamma}_{w}$ を基準にして 比較すれば, HDPE に対する組み合わせ PS 試料が流動性の良い あのになって行くに従って, 徐々に $c^{*}-c$ 曲線が $c^{*}=c$ 直線の下 側から上側に出るように変化するととがわかる。すなおち， $c^{*}=$ $c$ 直線をはさんで $c^{*}-c$ 曲線が下側から上側に回転してせり上って 行くかのように変化して行く挙動状況を示す. 特に $c=0.75$ 付近 での変化か顕著である。また, PS4·HDPE 混合試料の組み合わ 女以外の他の組み合わせにおける各混合試料の流動性は， $c=0.5$ の付近を前後に $c$ がそれより小さい領域では流れやすい成分の HDPE に影響され，cがそれより大きい領域では流れにくい成分 のPS に影響される挙動をすることがわかる。なお，PS4·HDPE 混合試料のように，混合試料が流れにくい方の単一成分試料より 屯更に流机にくくなるような特異な流動挙動をする場合の $c^{*}$ は 1よりあ大きな值となる．しかし，混合試料が流れやすい方の単 一成分試料よりも更に流れやすいように流動する現象が生じた場 合の $c^{*}$ は負の值となる.

式(1)と $\tau_{w}-\dot{\gamma}_{w}$ 流動特性曲線を用いて $\dot{\gamma}_{w} に$ 対する混合率補正係

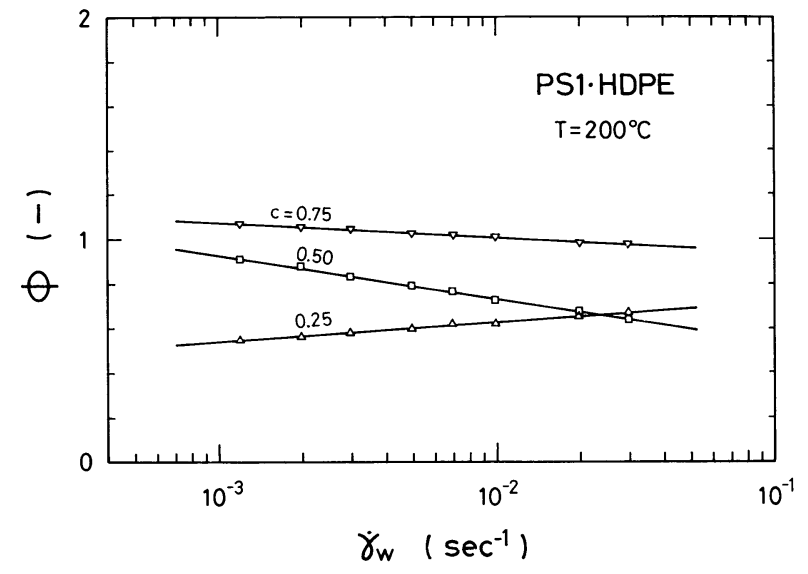

Fig. 14 Relationship between $\phi$ and $\dot{\gamma}_{w}$ for blended PS1·HDPE samples.
数 $\phi$ を計算し, $\ln \dot{\gamma}_{w}$ に対して $\phi$ をプロットした結果をFig. 14〜 17 亿示す。乙れらの図から明らかな様に, PS1·HDPE 混合試料 での $\dot{\gamma}_{w}$ が大い領域を除けば，cの大きい順に上から下に各 $\phi-\dot{\gamma}_{w}$ 線は位置している. PS1·HDPE〜PS3·HDPE の各組み合わせの 試料は各混合率の $\phi-\ln \dot{\gamma}_{w}$ 線図は直線で近以することがで, 式(2) で $i=1$ とした形で表すことができる. PS1·HDPE と $\dot{\gamma}_{w}$ が大き な所での PS4.HDPE 混合試料における $c=0.25$ の $\phi-\ln \dot{\gamma}_{w}$ 関係

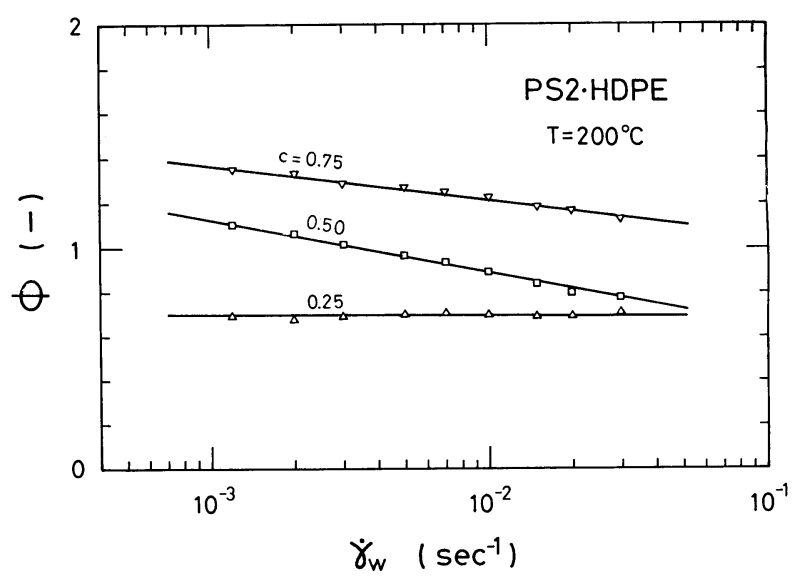

Fig. 15 Relationship between $\phi$ and $\dot{\gamma}_{w}$ for blended PS2·HDPE samples.

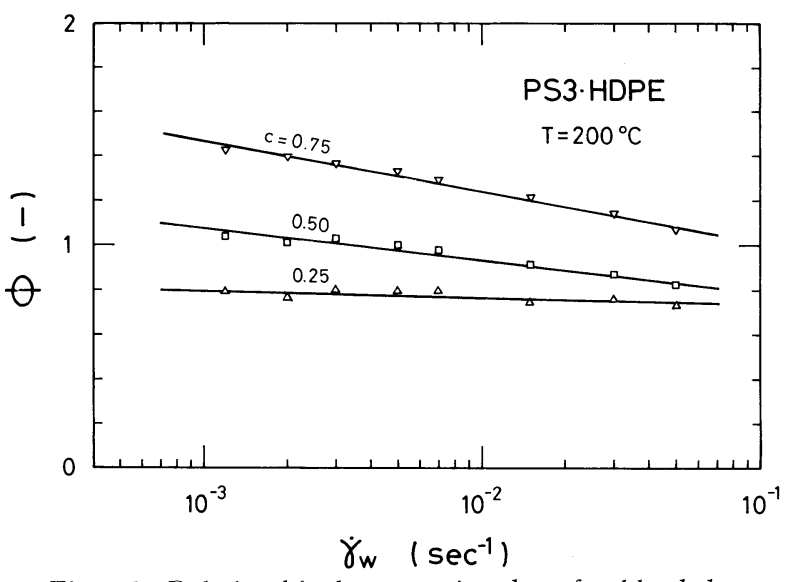

Fig. 16 Relationship between $\phi$ and $\dot{\gamma}_{w}$ for blended PS3·HDPE samples.

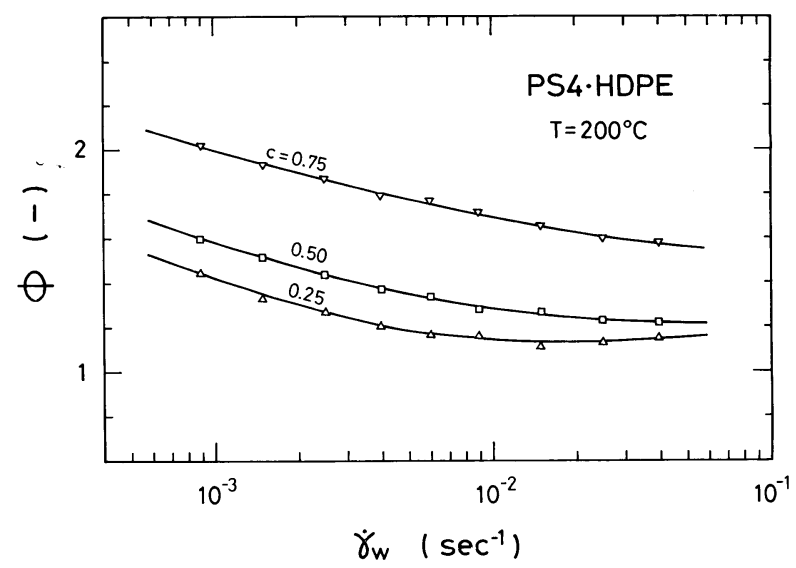

Fig. 17 Relationship between $\phi$ and $\dot{\gamma}_{w}$ for blended PS4·HDPE samples. 
が増加関数的である以外，他の混合試料の $\phi-\ln \dot{\gamma}_{w}$ 関係は減少関 数的である. Fig. 17 に示す PS4.HDPE 混合試料の $\phi$ - $\ln \dot{\gamma}_{w}$ 関 係は曲線的であり, 式(2)で $i=2$ 以上で近似される. PS1·HDPE 混合試料は $c$ が小さくなるに従って $\phi$ は約 1 よりあ小さくなり, PS4·HDPE 混合試料では $c$ が小さくなるに従って $\phi$ は 1 亿近付 く傾向にある. すなわち，Fig. 14〜17 を重㸚合わせて眺めると， HDPE に対し PS1 から PS4 と各組み合わせて行くに従って, $\phi-\ln \dot{\gamma}_{w}$ 線図は $\phi$ 軸に沿って $\phi$ の值が増加する方向に移動変化し て行くことがわかる． $\phi$ 值がcや $\dot{\gamma}_{w}$ とともに変化する場合, 混合試料の流動特性が流れにくい方の成分の流動性に支配される 程度が大である場合は $\phi$ が 1 よりも大きくなり，逆に流れやすい 成分の流動性に支配される程度が大である場合は $\phi$ は 1 よりも小 となる。相加性が成り立つ場合は $\phi=1$ となる。

相加性が成り立たず，一方の単一成分試料の流動性に支配され る現象は, 各成分の配置の仕方，すなわちどちらの成分が「海」 あるいは「島」の役割をするか ${ }^{14)}$ ，によって変化するあのと思わ れる.cに比例する流動性より屯流動しやすい挙動は, 異種ポリ マーの界面での滑りなどによって生じる場合も考えられる。また， 流動しにくくなる挙動は混合状態における各成分の流動場での変 形能や，互いの干涉によって影響を受けるのではないかと思われ る. 当実験で観測されたような $c^{*}>1$ になる特異現象は, むとの 単一成分試料それぞれからは予測しにくい性質であり, 非相溶性 樹脂を混合したことによって生じた新たな挙動である。この場合 のような流動機構等は複雑であるが興味ある現象であり、今後更 に検討を要し解明されることが期待される.

\section{4. 結訔}

流動性の異なる 4 種類の PS と HDPE を, それぞれ組み合わ せた分散系複合高分子溶融体の流動特性を検討した結果, 本研究 での試料および測定範囲では以下のことが明らかになった。

1） HDPE に対し流動性の良くないPSを組み合わせた場合に は, 各混合率の混合試料の流動特性曲線は各単一成分試料の曲線 間に位置するが，流動性の良いPSを組み合わせるに従って， $c=$ 0.75 の曲線は流れにくい方の単一成分試料である PS の曲線と交 差する. 更に，もっと流動性の良い PS と組み合わせた場合には， この混合率の曲線は完全に流れにくい方の PS 曲線の外側に位置 する特異な流動挙動を示すようになる.

2）各組み合わせ試料とも相加性が成り立たず，PS4 に対する
あの以外の混合試料の流動特性は $c$ が小さい領域では, HDPE成 分の流動性によって影響を受ける程度が大きく，cが大きくなる と PS 成分による影響の程度が大きくなる. PS4 との組み合わせ 試料では $c$ 全領域にわたって PS 成分に影響される.

3) HDPE 飞対し流動性の良いPS が組み合わされるに従って, 各混合試料の流動性は流れにくい方の成分である PS の流動性に 支配される程度が大きくなって行き, $c^{*}$ は $c$ よりも大きな值を取 るようになる，そして， $c=0.75$ 付近では $c^{*}$ は 1 を超えるように さえなる。

4） $\phi$ と $\dot{\gamma}_{w}$ の関係はほぼ直線的であるが，一番流動性のよい PS と HDPE の組み合わせにおいては曲線的になった。

（1978年10月25日 第26回レオロジー討論会にて講演）

\section{文献}

1）箕浦有二, 高分子, 6, 327 (1957).

2）笠島正行, 東大・森研談話会資料 (1972).

3）後藤邦夫,“ポリマーブレンド”, p. 13 (1970), 日刊工業 新聞社.

4) Barentsen, W.M., and D. Heikens, Polymer, 14, 579 (1973).

5）山口章三郎, 工業材料, 24, No. 9, 79 (1976), No. 10, 63 (1976).

6）金原 勲, 高分子学会プラスチック研究会資料, $78 / 3,1$ (1978).

7) Hill, A.S., and B. Maxwell, Polym. Eng. Sci., 10, 289 (1970).

8) Han, C.D., and T.C. Yu, Polym. Eng. Sci., 12, 81 (1972).

9）笠島正行, 森芳郎, 化学工学, 37, 915 (1973).

10）笠島正行，レオロジー隗談会資料，1 (1974).

11) Han, C.D., and Y.W. Kim, J. Appl. Polym. Sci., 19, 2831 (1975).

12) Han, C.D., "Rheology in Polymer Processing", p. 165 (1976), Academic Press.

13) Kasajima, M., A. Suganuma, D. Kunii, and K. Ito, Proc. Int. Conf. Polym. Processing, to be published.

14）高柳素夫, 高分子, 10, 289 (1961). 